\title{
STUDY OF THE SOIL-PLANT (CARROT)-ANIMAL CYCLE OF NUTRITIVE AND HAZARDOUS MINERALS IN A RABBIT MODEL
}

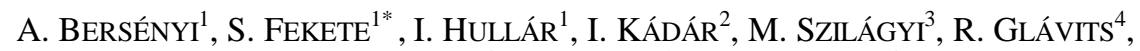 \\ Margit KULCSÁR ${ }^{1}$, M. MÉZES ${ }^{5}$ and L. ZÖLDÁG ${ }^{1}$ \\ ${ }^{1}$ University of Veterinary Science, H-1400 Budapest, P.O. Box 2, Hungary; ${ }^{2}$ Soil and \\ Agrochemical Research Institute of the Hungarian Academy of Sciences, Budapest; \\ ${ }^{3}$ Research Institute for Animal Breeding and Nutrition, Herceghalom; ${ }^{4}$ Central Veterinary \\ Institute, Budapest; ${ }^{5}$ University of Agricultural Sciences, Gödöllő, Hungary
}

(Received September 15, 1998; accepted February 19, 1999)

Carrots were grown on soils polluted by heavy metal salts. Each particular microelement reached a high concentration [molybdenum (Mo) 39.00, cadmium (Cd) 2.30, lead $(\mathrm{Pb}) 4.01$, mercury $(\mathrm{Hg}) 30.00$, and selenium $(\mathrm{Se}) 36.20 \mathrm{mg} / \mathrm{kg}$ dry matter] in the carrot. In a metabolic balance trial conducted with 15 male and $15 \mathrm{fe}-$ male New Zealand White rabbits, the control animals $(\mathrm{n}=5)$ were fed ad libitum with concentrate as basal diet, while the other rabbits received the basal diet and carrots containing the particular microelement. Blood samples were taken to determine the activity of serum enzymes. To investigate the metabolism of $\mathrm{Mo}, \mathrm{Cd}, \mathrm{Pb}, \mathrm{Hg}$ and $\mathrm{Se}$, samples were taken from the heart, liver, lungs, kidneys, spleen, ovaries/testicles, entire digestive tract, adipose tissue, femur, hair, faeces and urine. Carrot had significantly higher digestibility for all nutrients than the rabbit concentrate. Carrot samples of high $\mathrm{Pb}$ content had the lowest digestibility of crude protein. The microelements differed in their rate of accumulation in the organs examined: Mo and $\mathrm{Cd}$ accumulated in the kidneys, $\mathrm{Pb}$ in the kidneys, liver, bones and lungs, $\mathrm{Hg}$ in the kidneys and liver, while Se in the liver, kidneys and heart. The proportions of microelements eliminated from the body either via the faeces and urine (Mo $80.18 \%$ and Se

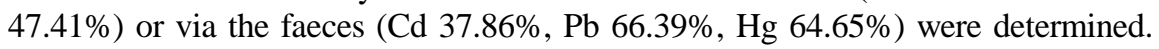
Pathohistological examination revealed that the rate of spermatogenesis was reduced in the $\mathrm{Mo}, \mathrm{Cd}, \mathrm{Pb}$ and $\mathrm{Hg}$ groups compared to the control. Lead, $\mathrm{Cd}$ and $\mathrm{Hg}$ intake resulted in a considerable decrease in gamma-glutamyltransferase (GGT) and in an increase of alkaline phosphatase (ALP) activity because of damages to the kidneys and bones. All experimental treatments decreased the activity of cholinesterase (CHE) because of lesions in the liver.

Key words: Heavy metals, soil-plant-animal chain, rabbit, carrot, serum enzymes

*Corresponding author; E-mail: Sandor.Fekete@iif.hu; Fax: (36 1) 3429734 
In addition to lead $(\mathrm{Pb})$, cadmium $(\mathrm{Cd})$ has been the subject of numerous studies focusing especially on heavy metal pollution. One of the main reasons why $\mathrm{Cd}$ is a hazardous chemical is that it can enter the food chain (Schenkel, 1988): its biological half-life is rather long (17 years for humans). Epidemiological studies have revealed that $\mathrm{Cd}$ exposure is correlated with the occurrence of human essential hypertension and $\mathrm{Cd}$ concentration of the adrenal gland. Cadmium taken up into the body binds to metallothionein in the liver and kidneys. It can severely damage the kidneys, testicles and ovaries (National Research Council, 1980). Because of the varying metallothionein concentrations and dissimilar metabolic pathways in individual species, values cannot be readily extrapolated from one animal species to another. Data for rabbits are especially scanty. Stowe et al. (1972) carried out a 200-day trial in 3-month-old rabbits, and found that treatment with $160 \mathrm{ppm} \mathrm{Cd}$ (administered in the form of $\mathrm{CdSO}_{4}$ ) resulted in splenic atrophy, changes in blood parameters, and liver and kidney injury. Fairchild et al. (1977) reported that oral administration of a single dose $(43 \mathrm{mg} / \mathrm{kg}$ ) of cadmium (in the form of $\mathrm{CdSO}_{4}$ ) was lethal to rabbits. No data were available in the literature on the effect that $\mathrm{Cd}$ naturally taken up from the soil by plants exerted on rabbits.

\section{Materials and methods}

Carrot samples (Table 1A) were obtained from the exposure tolerance experiments conducted by the Soil and Agrochemical Research Institute of the Hungarian Academy of Sciences (Budapest). During the experimental period, extremely high doses $(810 \mathrm{~kg} / \mathrm{ha})$ of $\mathrm{Mo}$ [in the form of $\left(\mathrm{NH}_{4}\right)_{6} \mathrm{Mo}_{7} \mathrm{O}_{24} \times 4 \mathrm{H}_{2} \mathrm{O}$ ], $\mathrm{Cd}$ [in the form of $\mathrm{CdSO}_{4} \times 8 \mathrm{H}_{2} \mathrm{O}$ ], $\mathrm{Hg}$ [in the form of $\mathrm{HgCl}_{2}$ ], $\mathrm{Pb}$ [in the form of $\mathrm{Pb}\left(\mathrm{NO}_{3}\right)_{2}$ ] and $\mathrm{Se}$ [in the form of $\mathrm{Na}_{2} \mathrm{SeO}_{3}$ ] fertilizers were applied onto the soil and the rate of accumulation of the above heavy metals in carrots was determined. For more technical details see Biacs et al. (1995). Carrot samples with high microelement concentrations (Mo 39.00, $\mathrm{Cd} 2.30, \mathrm{~Pb} 4.01, \mathrm{Hg} 30.00$, and Se $36.20 \mathrm{mg} / \mathrm{kg}$ dry matter) were selected.

The animal experiment was carried out in the animal house of the Department of Animal Breeding and Nutrition of the University of Veterinary Science. A total of 15 male and 15 female New Zealand White rabbits (average body weight: $2300 \pm 87 \mathrm{~g}$ ), placed in individual hutches for the metabolic experiment, were used to determine the apparent total tract digestibilities of a breeding rabbit concentrate used as a basal diet (Table 1B). Subsequently the 30 rabbits were divided into six groups (one control and five experimental groups), 2-3 males and females in each. The control group continued to receive the basal diet ad libitum, while all five animals in each experimental groups were pre-fed over a period of 10 days. During that period the daily intake of basal diet was re- 
stricted to $50 \mathrm{~g}$ and a carrot diet containing $\mathrm{Mo}, \mathrm{Cd}, \mathrm{Pb}, \mathrm{Hg}$ and $\mathrm{Se}$ was offered ad libitum. This was followed by a metabolic experiment when a 'feed mixture' containing basal diet and carrot was fed, and the digestibility of nutrients for each of the carrot samples was calculated by the differential experimental formula (Fekete and Gippert, 1982). The mixing ratio, as the actual nutrient ratio in dry matter taken up from carrot, was calculated on the basis of basal diet analysis and the amount of carrot samples fed and remaining. During both experimental periods the total daily urine volume was collected from each animal. Following the metabolic experiment, after the 20-day feeding of carrot samples, blood samples were taken from each animal, and the following blood parameters were determined at the Research Institute for Animal Breeding and Nutrition (Herceghalom) and at the University of Agricultural Sciences (Gödöllö): aspartate aminotransferase (AST), alanine aminotransferase (ALT), gamma-glutamyltransferase (GGT), alkaline phosphatase (ALP), cholinesterase (CHE), creatine kinase (CK), cholesterol (CHOL), triglyceride (TRIG), creatinine (CREA), malondialdehyde, glutathione peroxidase (GSH-Px) and reduced glutathione. The rabbits were weighed, killed painlessly by an overdose of anaesthetic, and subjected to pathological examination. The heart, liver, lungs, kidneys, spleen, ovaries/testicles and entire digestive tract were weighed. Appropriate samples taken from the above organs as well as from the thyroid gland, femoral muscle, jejunum, ileal ampulla and sternum were fixed in buffered formaldehyde solution. In addition to the above-mentioned samples, adipose tissue, femur, hair, faeces and urine samples were taken for chemical analysis including determination of the $\mathrm{Mo}, \mathrm{Cd}, \mathrm{Pb}, \mathrm{Hg}$ and $\mathrm{Se}$ content of each sample. Samples from animal tissues (kidney, liver, muscle, brain, testicle, ovary, blood, lung and heart) were prepared by lyophilisation, bone, hair and faeces were dried in an oven, and urine was used in natural form. Approximately $1 \mathrm{~g}$ samples of animal tissues, hair or faeces, dried at $105{ }^{\circ} \mathrm{C}$, were digested in teflon bombs at $80{ }^{\circ} \mathrm{C}$ for $4 \mathrm{~h}$ with a mixture of $10 \mathrm{ml}$ of $65 \mathrm{~m} / \mathrm{m} \% \mathrm{HNO}_{3}$ and $2 \mathrm{ml} 30 \mathrm{~m} / \mathrm{m}^{2} \mathrm{H}_{2} \mathrm{O}_{2}$. The digest was diluted to $50 \mathrm{ml}$ with deionised water. Having extremely low amounts of animal tissues (e.g. brain, testicle, ovary) the weighed materials (acid, peroxide and deionised water) were reduced proportionally. Approximately $3.0 \mathrm{~g}$ of bone was digested 3 times with $\mathrm{HNO}_{3}+\mathrm{H}_{2} \mathrm{O}_{2}$ as mentioned above. The final volume of the digest was $150 \mathrm{ml}$. From the urine samples, $150-200 \mathrm{ml}$ was concentrated to $20 \mathrm{ml}$, digested with $10 \mathrm{ml} \mathrm{HNO}_{3}+2 \mathrm{ml} \mathrm{H}_{2} \mathrm{O}_{2}$ and diluted to $50 \mathrm{ml}$. Before analysis the samples were diluted 4-fold because of the high concentration of $\mathrm{NH}_{4} \mathrm{NO}_{3}$ which would have destroyed the plasma without dilution. The analysis of minerals in the $\mathrm{HNO}_{3}+\mathrm{H}_{2} \mathrm{O}_{2}$ digest was performed by using a plasma emission spectrometer (ICP), type JY 24 (JOBEN YVON), in a sequential mode at the following wavelengths: Mo 202.03, Cd 228.802, Pb 220.353, Hg 194.227, and Se $196.03 \mathrm{~nm}$. 
BERSÉNYI et al.

Table 1A

Nutrient content of the basal diet and of carrots containing microelements, on air-dry basis (\%)

\begin{tabular}{lrrrrrr}
\hline \multicolumn{1}{c}{ Nutrients } & Basal diet & $\begin{array}{c}\text { Carrot } \\
\text { Mo }\end{array}$ & $\begin{array}{c}\text { Carrot } \\
\text { Cd }\end{array}$ & $\begin{array}{c}\text { Carrot } \\
\mathrm{Pb}\end{array}$ & $\begin{array}{c}\text { Carrot } \\
\mathrm{Hg}\end{array}$ & \multicolumn{1}{c}{$\begin{array}{c}\text { Carrot } \\
\text { Se }\end{array}$} \\
\hline DM & 91.88 & 18.88 & 20.61 & 21.26 & 19.47 & 22.49 \\
Air DM & 91.88 & 90.12 & 91.63 & 90.76 & 89.09 & 91.52 \\
Ash & 7.03 & 4.93 & 5.46 & 5.07 & 5.11 & 5.39 \\
OM & 84.85 & 85.19 & 86.17 & 85.69 & 83.98 & 86.13 \\
CP & 15.20 & 10.60 & 10.30 & 9.80 & 11.10 & 11.10 \\
CF & 11.99 & 4.80 & 4.83 & 4.73 & 5.55 & 4.60 \\
EE & 1.80 & 2.70 & 1.78 & 2.28 & 2.28 & 2.08 \\
NFE & 55.86 & 67.09 & 69.26 & 68.88 & 65.05 & 68.35 \\
\hline
\end{tabular}

$\mathrm{DM}=$ dry matter; $\mathrm{OM}=$ organic matter; $\mathrm{CP}=$ crude protein; $\mathrm{CF}=$ crude fibre; $\mathrm{EE}=$ ether extract; $\mathrm{NFE}=$ nitrogen-free extract

\section{Table 1B}

Ingredients of the basal diet

\begin{tabular}{lr}
\hline \multicolumn{1}{c}{ Ingredients } & $\%$ \\
\hline Barley & 38.6 \\
Wheat & 10.0 \\
Maize & 15.0 \\
Wheat bran & 5.7 \\
Extracted sunflower meal I & 16.5 \\
Alfalfa meal I & 11.7 \\
Lysine & 0.2 \\
Limestone & 1.5 \\
Salt & 0.3 \\
Vitamin-mineral premix & 0.5 \\
\hline Total & 100.0 \\
\hline
\end{tabular}

Statistical calculations. A nonsequential determination of least squares means and analysis of variance were carried out for the digestibility coefficients as well as for the data on mineral concentrations and enzyme activities. Student's $t$ test (for pair-wise comparison of group means) and one-way analysis of variance giving the least significant difference (LSD) at the level of 5\% according to the procedure of SAS (Snedecor and Cochram, 1967; SAS, 1988) were used for the statistical analyses. 


\section{Results}

The digestibilities of nutrients in the basal diet and in the treated carrots are shown in Table 2 . The carrot diet covered $43 \%$ of the daily dry matter requirements, which meant the 'feed mixture' in the combined feed utilization experiment. The data presented in this paper provide evidence that the digestibility of carrots for each nutrient tended to be significantly higher than that of the basal diet. The lowest crude protein digestibility was found for samples containing $\mathrm{Pb}$, while the lowest digestibility of ether extract was found for samples containing $\mathrm{Hg}$ and $\mathrm{Cd}$. No differences were observed in the digestibility of other nutrients in the carrot samples.

Table 2

Digestibility of the basal diet and of carrots containing microelements, $\%$ (mean $\pm \mathrm{SD} ; \mathrm{n}=5$ )

\begin{tabular}{ccccccc}
\hline \multirow{2}{*}{ Nutrients } & Basal diet & $\begin{array}{c}\text { Carrot } \\
\text { Mo }\end{array}$ & $\begin{array}{c}\text { Carrot } \\
\text { Cd }\end{array}$ & $\begin{array}{c}\text { Carrot } \\
\text { Pb }\end{array}$ & $\begin{array}{c}\text { Carrot } \\
\text { Hg }\end{array}$ & $\begin{array}{c}\text { Carrot } \\
\text { Se }\end{array}$ \\
\hline DM & $74.80^{\mathrm{a}}$ & $81.64^{\mathrm{c}}$ & $79.24^{\mathrm{b}}$ & $80.11^{\mathrm{c}}$ & $78.78^{\mathrm{b}}$ & $79.81^{\mathrm{c}}$ \\
SD & 2.36 & 2.97 & 2.47 & 1.90 & 1.25 & 0.88 \\
OM & $75.07^{\mathrm{a}}$ & $82.25^{\mathrm{c}}$ & $80.03^{\mathrm{b}}$ & $80.61^{\mathrm{b}}$ & $79.56^{\mathrm{c}}$ & $81.37^{\mathrm{d}}$ \\
SD & 2.64 & 2.83 & 2.41 & 2.10 & 1.18 & 0.63 \\
CP & $75.63^{\mathrm{a}}$ & $79.81^{\mathrm{be}}$ & 78.34 & $75.57^{\mathrm{f}}$ & 78.45 & 77.47 \\
SD & 2.32 & 2.41 & 2.79 & 2.22 & 2.79 & 2.12 \\
CF & $28.63^{\mathrm{a}}$ & $42.56^{\mathrm{d}}$ & $38.02^{\mathrm{c}}$ & $44.91^{\mathrm{d}}$ & $39.12^{\mathrm{c}}$ & $43.44^{\mathrm{d}}$ \\
SD & 3.11 & 3.86 & 3.39 & 2.86 & 3.53 & 2.94 \\
EE & $72.17^{\mathrm{a}}$ & $81.27^{\mathrm{dg}}$ & $74.27^{\text {he }}$ & $78.03^{\mathrm{cf}}$ & $74.75^{\mathrm{he}}$ & $75.22^{\mathrm{b}}$ \\
SD & 1.34 & 1.70 & 2.66 & 2.26 & 2.28 & 2.04 \\
NFE & $81.34^{\mathrm{a}}$ & $87.29^{\mathrm{d}}$ & $87.08^{\mathrm{d}}$ & $87.20^{\mathrm{d}}$ & $86.41^{\mathrm{d}}$ & $87.88^{\mathrm{d}}$ \\
SD & 1.21 & 1.96 & 1.54 & 1.43 & 0.90 & 0.81 \\
\hline
\end{tabular}

$\mathrm{DM}=$ dry matter; $\mathrm{OM}=$ organic matter $\mathrm{CP}=$ crude protein $\mathrm{CF}=$ crude fibre; $\mathrm{EE}=$ ether extract; $\mathrm{NFE}=\mathrm{N}$-free extract; a-b: P $<0.05 ;$ a-c: $\mathrm{P}<0.01 ; \mathrm{a}-\mathrm{d}: \mathrm{P}<0.001$; e-f: $\mathrm{P}<0.05 ; \mathrm{g}-\mathrm{h}: \mathrm{P}<0.01$

Carrot samples containing $\mathrm{Cd}$ resulted in a reduction of heart and liver weight. The heavy metal contents of the diet, urine, faeces and various organs and tissues are presented in Table 3.

The values clearly show that the rate of accumulation of microelements is different in the individual organs: Mo and Cd showed the highest accumulation in the kidneys, $\mathrm{Pb}$ in the kidneys, liver, bones and lungs, $\mathrm{Hg}$ in the kidneys and liver, while Se in the liver, kidneys and heart. 
Table 3

$\mathrm{Mo}, \mathrm{Cd}, \mathrm{Pb}, \mathrm{Hg}$ and Se content of basal diet, carrots, faeces, urine and different organs (ppm; $\mathrm{n}=5$ )

\begin{tabular}{|c|c|c|c|c|c|c|c|c|c|c|}
\hline & $\begin{array}{c}\text { Basal diet } \\
\text { Mo }\end{array}$ & $\begin{array}{c}\text { Carrot } \\
\text { Mo }\end{array}$ & $\begin{array}{l}\text { Basal diet } \\
\quad \mathrm{Cd}\end{array}$ & $\begin{array}{c}\text { Carrot } \\
\mathrm{Cd}\end{array}$ & $\begin{array}{c}\text { Basal diet } \\
\mathrm{Pb}\end{array}$ & $\begin{array}{c}\text { Carrot } \\
\mathrm{Pb}\end{array}$ & $\begin{array}{c}\text { Basal diet } \\
\mathrm{Hg}\end{array}$ & $\begin{array}{c}\text { Carrot } \\
\mathrm{Hg}\end{array}$ & $\begin{array}{c}\text { Basal diet } \\
\mathrm{Se}\end{array}$ & $\begin{array}{c}\text { Carrot } \\
\mathrm{Se}\end{array}$ \\
\hline Feed & 0.527 & 39.000 & 0.140 & 2.300 & 1.580 & 4.010 & 0.000 & 30.000 & 0.000 & 36.200 \\
\hline Frenes & 0.416 & 25.340 & 0.460 & 9.072 & 3.022 & 9.380 & 0.000 & 32.060 & 0.000 & 11.703 \\
\hline Urine & 0.417 & 6.602 & 0.000 & 0.004 & 0.040 & 0.046 & 0.000 & 0.016 & 0.058 & 3.238 \\
\hline Heart & 0.060 & 1.234 & 0.000 & 0.000 & 0.388 & 0.000 & 0.000 & 0.000 & 0.584 & 19.400 \\
\hline Lungs & 0.033 & 1.206 & 0.007 & 0.029 & 0.644 & 0.507 & 0.000 & 0.000 & 0.727 & 14.748 \\
\hline Liver & 1.262 & 1.878 & 0.119 & 0.722 & 1.717 & 1.846 & 0.000 & 3.530 & 1.738 & 64.950 \\
\hline Kidney & 0.754 & 3.464 & 1.119 & 2.590 & 0.042 & 4.664 & 0.000 & 50.480 & 4.100 & 38.550 \\
\hline Spleen & 0.000 & 1.083 & 0.012 & 0.000 & 0.759 & 0.151 & 0.000 & 0.080 & 1.990 & 15.350 \\
\hline Adipose tissue & 0.000 & 0.060 & 0.000 & 0.000 & 0.141 & 0.060 & 0.000 & 0.000 & 0.000 & 0.634 \\
\hline Muscle & 0.000 & 0.369 & 0.000 & 0.000 & 0.000 & 0.129 & 0.000 & 0.132 & 1.327 & 13.490 \\
\hline Bone & 0.000 & 1.202 & 0.000 & 0.000 & 0.000 & 0.649 & 0.000 & 0.000 & 0.000 & 3.207 \\
\hline Hair & 0.000 & 0.409 & 0.004 & 0.003 & 0.359 & 0.000 & 0.000 & 0.000 & 1.371 & 2.695 \\
\hline
\end{tabular}


Table 4 shows the elimination of heavy metals via the urine and faeces and their accumulation in the tissues, expressed as a proportion of the amount taken up with the feed. It can be seen that Mo and Se are excreted from the body mainly through the faeces and urine, while $\mathrm{Cd}, \mathrm{Pb}$ and $\mathrm{Hg}$ leave the body almost exclusively via the faeces. Cadmium builds up in the tissues in the largest quantity, followed by $\mathrm{Se}, \mathrm{Hg}, \mathrm{Pb}$ and $\mathrm{Mo}$ in decreasing order. The proportion of microelements eliminated from the body via the faeces and urine as a percentage of their intake was $80.18 \%$ for $\mathrm{Mo}, 37.86 \%$ for $\mathrm{Cd}, 66.39 \%$ for $\mathrm{Pb}, 64.65 \%$ for $\mathrm{Hg}$, and $47.41 \%$ for Se.

Table 4

Intake, excretion and deposition of microelements and their proportions $(n=5)$

\begin{tabular}{|c|c|c|c|c|c|c|}
\hline & & \multirow{2}{*}{ Intake } & \multicolumn{3}{|c|}{ Excretion } & \multirow{2}{*}{ Deposition } \\
\hline & & & via faeces & via urine & total & \\
\hline \multirow[t]{2}{*}{ Mo, mg/day } & & 1.398 & 0.362 & 0.759 & 1.121 & 0.241 \\
\hline & $\%$ & 100.000 & 25.890 & 54.290 & 80.180 & 19.820 \\
\hline \multirow[t]{2}{*}{$\mathrm{Cd}, \mathrm{mg} / \mathrm{day}$} & & 0.103 & 0.039 & - & 0.039 & 0.064 \\
\hline & $\%$ & 100.000 & 37.860 & 0.000 & 37.860 & 62.140 \\
\hline \multirow[t]{2}{*}{$\mathrm{Pb}, \mathrm{mg} /$ day } & & 0.241 & 0.157 & 0.003 & 0.160 & 0.081 \\
\hline & $\%$ & 100.000 & 65.140 & 1.240 & 66.390 & 33.610 \\
\hline \multirow[t]{2}{*}{$\mathrm{Hg}, \mathrm{mg} / \mathrm{day}$} & & 0.116 & 0.055 & 0.020 & 0.075 & 0.041 \\
\hline & $\%$ & 100.000 & 47.410 & 17.240 & 64.650 & 35.350 \\
\hline \multirow[t]{2}{*}{$\mathrm{Se}, \mathrm{mg} / \mathrm{day}$} & & 1.350 & 0.187 & 0.453 & 0.640 & 0.710 \\
\hline & $\%$ & 100.000 & 13.850 & 35.550 & 47.41 & 52.59 \\
\hline
\end{tabular}

Immediately before slaughter, the body weight of experimental rabbits was significantly lower $(\mathrm{P}<0.05)$ than that of the control animals (Table 5). This can probably be attributed to the fact that the animals' dry matter uptake from the carrot diet was rendered difficult by physical factors rather than by the heavy metal content of the carrot. This is also supported by the finding that the body weight of the experimental groups did not differ. Histological examination revealed that the rate of spermatogenesis in the testis was reduced in the $\mathrm{Mo}, \mathrm{Cd}$, $\mathrm{Pb}$ and $\mathrm{Hg}$ groups as compared to the controls. A large number of syncytial giant cells and degenerated cells indicating abnormal meiotic divisions were found among the spermatogenic cells. Follicles containing healthy ova at different developmental stages were found in the ovaries of some does in the Mo, Se and control groups, but signs indicative of actual ovulation (corpus luteum) were not found. 
Table 5

Weight of organs, $g($ mean $\pm \mathrm{SD} ; \mathrm{n}=5)$

\begin{tabular}{cccrrrr}
\hline Group & Body weight & Heart & Lungs & Liver & Spleen & Kidney \\
\hline Control & $2790^{\mathrm{a}}$ & $7.46^{\mathrm{a}}$ & 11.56 & 77.19 & 1.58 & 15.56 \\
SD & 193 & 1.28 & 1.15 & 7.13 & 0.37 & 1.68 \\
Mo & $2484^{\mathrm{b}}$ & 6.18 & 12.45 & 78.30 & 1.36 & 15.30 \\
$\mathrm{SD}$ & 124 & 0.85 & 2.24 & 6.56 & 0.10 & 0.93 \\
$\mathrm{Cd}$ & $2522^{\mathrm{b}}$ & $6.02^{\mathrm{b}}$ & 14.09 & $63.94^{\mathrm{b}}$ & 1.42 & 15.19 \\
$\mathrm{SD}$ & 99 & 0.40 & 2.31 & 8.66 & 0.16 & 2.84 \\
$\mathrm{~Pb}$ & $2496^{\mathrm{b}}$ & 6.23 & 13.22 & 67.42 & 1.28 & 15.24 \\
$\mathrm{SD}$ & 134 & 0.75 & 1.30 & 9.63 & 0.17 & 1.65 \\
$\mathrm{Hg}$ & $2468^{\mathrm{b}}$ & 6.08 & 13.67 & 80.24 & 1.36 & 14.56 \\
$\mathrm{SD}$ & 146 & 0.71 & 2.04 & 6.81 & 0.17 & 1.50 \\
$\mathrm{Se}$ & $2515^{\mathrm{b}}$ & 6.16 & 13.56 & 78.90 & 1.31 & 14.46 \\
$\mathrm{SD}$ & 370 & 0.87 & 1.74 & 13.54 & 0.15 & 1.15 \\
\hline
\end{tabular}

a-b: $\mathrm{P}<0.05$

With regard to changes in blood parameters (Table 6), it should be noted that $\mathrm{Cd}$ intake resulted in a considerable decrease in GGT and an increase in ALP activity. Both $\mathrm{Cd}$ and $\mathrm{Hg}$ had a similar effect on GGT and ALP activity. All experimental treatments decreased the activity of cholinesterase. ALT, AST, CK and creatinine levels did not show appreciable changes.

\section{Table 6}

Blood parameters I (means $\pm \mathrm{SD} ; \mathrm{n}=5)$

\begin{tabular}{|c|c|c|c|c|c|c|c|c|c|c|}
\hline Group & $\begin{array}{c}\text { AST } \\
\text { U/l }\end{array}$ & $\begin{array}{c}\text { ALT } \\
\text { U/l }\end{array}$ & $\begin{array}{c}\text { GGT } \\
\text { U/1 }\end{array}$ & $\begin{array}{c}\text { ALP } \\
\text { U/1 }\end{array}$ & $\begin{array}{l}\text { CHE } \\
\mathrm{U} / 1\end{array}$ & $\begin{array}{l}\text { CK } \\
\mathrm{U} / 1\end{array}$ & $\begin{array}{c}\mathrm{CHOL} \\
\mathrm{U} / \mathrm{l}\end{array}$ & $\begin{array}{c}\text { TRIG } \\
\text { g/l }\end{array}$ & $\begin{array}{c}\text { GHS-Px } \\
\text { U/g pro- } \\
\text { tein }\end{array}$ & $\begin{array}{l}\text { CREA } \\
\mu \mathrm{mol} / 1\end{array}$ \\
\hline Control & 4.40 & 22.40 & 8.00 & 55.20 & 735 & 364.0 & 1.81 & 1.150 & 20.00 & 109.80 \\
\hline $\mathrm{SD}$ & 1.01 & 4.49 & 9.36 & 31.10 & 365 & 90.3 & 0.31 & 0.300 & 8.17 & 9.32 \\
\hline Mo & 5.20 & 12.80 & 3.54 & 96.20 & 476 & 623.0 & 1.51 & 1.06 & 13.20 & 111.60 \\
\hline SD & 1.60 & 3.31 & 1.84 & 22.40 & 391 & 211.4 & 0.14 & 0.38 & 3.96 & 7.47 \\
\hline $\mathrm{Cd}$ & 3.60 & 17.60 & 1.88 & 123.00 & 429 & 640.0 & 1.97 & 0.714 & 17.00 & 119.80 \\
\hline SD & 1.49 & 12.05 & 1.34 & 27.90 & 224 & 90.6 & 0.18 & 0.237 & 5.83 & 6.55 \\
\hline $\mathrm{Pb}$ & 4.20 & 11.60 & 3.88 & 102.60 & 385 & 646.0 & 2.21 & 0.938 & 15.00 & 106.80 \\
\hline SD & 1.02 & 2.65 & 3.70 & 21.60 & 267 & 260.2 & 0.93 & 0.234 & 6.75 & 8.05 \\
\hline $\mathrm{Hg}$ & 5.00 & 17.80 & 1.40 & 96.40 & 339 & 523.0 & 1.97 & 0.900 & 13.60 & 113.20 \\
\hline SD & 1.26 & 7.24 & 0.38 & 6.97 & 585 & 82.7 & 0.36 & 0.208 & 10.20 & 15.79 \\
\hline $\mathrm{Se}$ & 9.75 & 17.25 & 2.50 & 70.50 & 412 & 522.0 & 2.37 & 0.827 & 13.20 & 102.50 \\
\hline SD & 5.97 & 2.86 & 1.75 & 12.80 & 258 & 224.0 & 1.39 & 0.117 & 0.82 & 4.15 \\
\hline
\end{tabular}

AST = aspartate aminotransferase; ALT = alanine aminotransferase; GGT = gamma-glutamyltransferase; $\mathrm{ALP}=$ alkaline phosphatase; $\mathrm{CHE}=$ cholinesterase; $\mathrm{CK}=$ creatine kinase; $\mathrm{CHOL}=$ cholesterol; $\mathrm{TRIG}=$ triglyceride $; \mathrm{GSH}-\mathrm{Px}=$ glutathione peroxidase CREA = creatinine 
The carrot diet high in Mo, Cd and Se increased GSH-Px activity by 22$50 \%$, that rich in $\mathrm{Pb}$ lowered it by $18 \%$, while $\mathrm{Hg}$ caused no change in the activity of that enzyme (Table 7).

Table 7

Blood parameters II (means $\pm \mathrm{SD} ; \mathrm{n}=5$ )

\begin{tabular}{|c|c|c|c|c|c|}
\hline \multirow{2}{*}{ Group } & \multirow{2}{*}{$\begin{array}{l}\text { Malondi- } \\
\text { aldehyde } \\
\text { mmol/l }\end{array}$} & \multicolumn{2}{|c|}{ Glutathione peroxidase } & \multicolumn{2}{|c|}{ Reduced glutathione } \\
\hline & & nkat/g ml & $\begin{array}{l}\text { nkat } / g \\
\text { protein }\end{array}$ & $\mu \mathrm{mol} / 1$ & $\mu \mathrm{mol} / \mathrm{g}$ \\
\hline Control & 2.12 & 2.20 & 2.48 & 109.87 & 1.41 \\
\hline SD & 0.14 & 0.23 & 0.52 & 22.30 & 0.24 \\
\hline Mo & 2.68 & 2.37 & 3.15 & 106.52 & 1.57 \\
\hline SD & 0.30 & 0.44 & 0.47 & 10.52 & 0.29 \\
\hline $\mathrm{Cd}$ & 2.65 & 2.30 & 3.71 & 116.74 & 2.25 \\
\hline SD & 0.45 & 0.59 & 0.75 & 8.57 & 0.29 \\
\hline $\mathrm{Pb}$ & 2.44 & 1.46 & 2.04 & 118.25 & 1.78 \\
\hline SD & 0.41 & 0.23 & 0.44 & 6.41 & 0.16 \\
\hline $\mathrm{Hg}$ & 2.83 & 2.01 & 2.73 & 123.61 & 1.89 \\
\hline SD & 0.64 & 0.16 & 0.40 & 6.20 & 0.26 \\
\hline $\mathrm{Se}$ & 2.56 & 2.31 & 3.02 & 122.08 & 1.73 \\
\hline SD & 0.43 & 0.10 & 0.38 & 2.70 & 0.36 \\
\hline
\end{tabular}

\section{Discussion}

From the results of this experiment it seems that the negative effect exerted by high concentrations of the microelements studied can hardly, if at all, be monitored by determining the usual parameters (body weight gain, digestibility coefficients). Further examinations have revealed that $\mathrm{Cd}$ is the element that accumulates in the tissues to the greatest extent, resulting in decreased heart and liver weight. From the fact that $\mathrm{Cd}, \mathrm{Pb}$ and $\mathrm{Hg}$ are excreted almost exclusively in the faeces it can be concluded that the absorbed amount of these elements remains in the body and their further excretion is very slow. In the trial of Hinesly et al. (1985) $60 \%$ of the retained Cd was found in the kidneys. The pathohistological examinations have shown that accumulation of these elements in the organism causes two main problems: it can impair spermatogenesis in breeding animals and pose a risk to consumers of products of animal origin.

As a rule, the uptake of $\mathrm{Pb}$ significantly reduced the activity of GGT and increased that of ALP. Cadmium and Hg loading also increased ALP activity. The altered activity of GGT and ALP indicates toxicity to the kidneys and the bones, respectively (Goreczky and Sós, 1983). All the treatments resulted in reduced activity of cholinesterase, which suggests damage of the liver parenchyma 
(Kaneko, 1989). AST, ALT and CK activity and creatine content of the blood remained practically unchanged. The carrot diet containing $\mathrm{Mo}, \mathrm{Cd}$ and $\mathrm{Se}$ increased the activity of GSH-Px by $20-50 \%$, that containing $\mathrm{Pb}$ decreased it, while the dietary uptake of $\mathrm{Hg}$ had no appreciable effect on the activity of that enzyme. The changes found in GSH-Px activity show that the experimental treatments altered the organism's immunity to free radicals (Fehér és Vereckei, 1985). According to Szilágyi et al. (1995), even the levels of metallothionein were significantly higher in the liver and kidneys of rabbits exposed to $\mathrm{Cd}$.

\section{Acknowledgements}

This study was supported by a grant from the Hungarian Scientific Research Fund (OTKA). The authors thank Mr. J. Koncz for the skilful chemical analysis of minerals.

\section{References}

Biacs, P. A., Daood, H. G. and Kadar, I. (1995): Effect of Mo, Se, Zn, and Cr treatments on the yield, element concentration, and carotenoid content of carrot. J. Agric. Chem. 43, 589-591.

Fairchild, E. J., Lewis, R. J. and Tatkin, R. L. (eds) (1977): Registry of Toxic Effects of Chemical Substances. DHEW Publ. No. (NIOSH) 78-104-B, 2, 526-534.

Fehér, J. and Vereckei, A. (1985): Importance of free residue reactions in medical science (in Hungarian). Biogal Pharmaceutical Factory, Medicina, Budapest.

Fekete, S. and Gippert, T. (1982): Suggestions for the standardization of metabolic experiments with rabbits (in Hungarian). Research Report, Research Institute of Animal Breeding and Nutrition, Herceghalom.

Goreczky, L. and Sós, J. (1983): Clinicochemical Laboratory Pocketbook (in Hungarian). Medicina, Budapest.

Hinesly, D. T., Hansen, L. G., Bray, D. J. and Redborg, K. E. (1985): Transfer of sludge-borne cadmium through plants to chickens. J. Agric. Food Chem. 33, 173-180.

Kaneko, J. J. (ed.) (1989): Clinical Biochemistry of Domestic Animals. Fourth Edition. Academic Press, Inc., New York-London-Tokyo.

National Research Council (1980): Mineral Tolerance of Domestic Animals. National Academy of Sciences, Washington, D. C.

SAS/STAT ${ }^{\text {TM }}$ User's Guide, Release 6.03 Edition (1988): SAS Institute, Inc., Cary, NC.

Schenkel, H. W. (1988): Nutritive Beeinflüssung des Stoffwechsel-verhalten von Cadmium bei Rind und Schwein. Habilitationsschrift, Hohenheim.

Snedecor, G. W. and Cochram, W. G. (1967): Statistical Methods. $6^{\text {th }}$ edition. Iowa State University Press, Ames.

Stowe, H. D., Wilson, M. and Goyer, R. A. (1972): Clinical and morphologic effects of oral cadmium toxicity in rabbits. Arch. Pathol. 94, 389-397.

Szilágyi, M., Fekete, S., Sankari, S., Hullár, I., Zsolnainé Harczi, I. and Kádár, I. (1995): Serum magnesium level and certain biochemical parameters in chicken and rabbits fed normal and heavy metals containing rations. Proc. Soc. Nutr. Physiol. 4, 90-98. 

